\title{
Efficiency of cultivation of intermediate cover crops as a biological element of the fertilizer system at no-till in the Crimea
}

\author{
Olga Tomashova ${ }^{1, *}$, Nicolay Osenniy ${ }^{1}$, Aleksandr Ilyin ${ }^{1}$, and Lubov Veselova ${ }^{1}$ \\ ${ }^{1}$ V.I. Vernadsky Crimean Federal University, 4, prosp. Vernadskogo, 295492, Simferopol, Russia
}

\begin{abstract}
The aim is to create the fundamental biologization's components of no-till system in the environment of foothill-steppe Crimea's area, to explore the effect of different kinds of cover crops on the indications of soil fertility, on the crop productivity and on the seeds' quality of the agricultural crops in terms of poor and unstable humidification. During the cultivation of the cover crops in no-till system the reserves of available humidity in the thickness of one metre were acceptable after the growing of vicia - 107,6 millimeters and on the control (without the cover crops) - 99,6 millimeters. The least reserves of available for the plants humidity were in the option with winter rape, as in pure form (59,3 millimeters), as in combination with vicia $(44,9$ millimeters). The highest crop productivity of cover crops' green mass was in all cases with the using of the multicomponent combination. It exceeds the crop productivity of the cover crops consisting of 1-2 and 3 sping crops more than twice as much and almost more than 10 times - the crop productivity of the winter rye.
\end{abstract}

\section{Introduction}

The progressive degradation processes in many regions of Russia give evidence concerning large violations during the creation of modern agroecosystem. Nowadays in practice of our country and the world practice from the huge number of the resource saving technology the most promising for the solving of this problem is so called nil technology (no-till technology). One of the direction for improving the present technology, which can provide the reproduce of soil fertility and increase of crops cultivation's profitability is the biologization of agriculture. The important role in it is assigned to the saturation of crop rotation with cops which improve the environment (including cover crops), which are calling to provide the soil enrichment with organic substance and nitrogen, to improve agro-physical and biological characteristics of soil.

For the nearest 20 years there is important problem for agricultural science and the society is to solve the global problem of food security and its consequences for the environment [1]. The poor harvest of crops and low quality of food products are aggravated by soil degradation and climate change, complicate the food insecurity, especially in

\footnotetext{
*Corresponding author: 777tom@bk.ru
} 
developing countries [2].

For the last years past you can meet more and more often in agricultural science the appeal to refuse from traditional system of treatment soil (TSTS) and turn to more environmentally friendly no-till system (NT).

The farming without soil treatment (NT) made the revolution in agricultural systems and allowed producers to manage large areas of land and to reduce energy, labor and equipment costs for the fighting against erosion, it also improved the soil condition and reduced greenhouse gas emission [3]. The analysis of the world's agriculture experience shows that most crops areas are cultivated according to the traditional technologies which include soil treatment and just on the $20-30 \%$ of crop areas is used no-till. At the same time NT system is gaining popularity all over the world thanks to its stable approaches [4], however many items of transition to this technology are still studied not enough.

The exploration of NT is developed in different directions. The review of numerous investigations has shown that during the implementation of NT was noted the improvement of soil quality, the reduction of the soil's organic matter mineralization and increase in yield $[5,6]$.

According to the long term experiment to study TSTS and NT there is clear differentiation of the food elements' content - after the plowing there is more uniform distribution of food elements over the entire arable horizon, after the plowing without turning over the top layer of the earth - the upper horizon was containing more food elements [7,8]. NT in well-structured soils doesn't affect the total number of pores, which lately does not have a negative impact on the development of the root system of plants [9]. At the same time in the ground is kept higher soil moisture content, that is especially important in dry regions [10].

Such differentiation affects not only redistribution of nutrients in the soil, but also weed plants' seeds. A significant number of them is accumulated in the upper $0-10 \mathrm{~cm}$ layer of soil [11]. Accumulated seeds in the upper layer provide a higher contamination of the sowing crops. However in the condition of dry weather they do not sprout due to the soil's dryness.

The problem of weed control in NT technology is easy solved by application of herbicides. At the same time there is more global problem - reproduction of fertility soils. For this purpose many scientists prefer cultivation of intermediate crops (siderates) in crop rotation and also leaving crop residues [12]. During the sowing of legumes cover crops the content of nitrates in the soil increases [13], perennial herbs have a positive effect on reducing erosion soil [14], which in the complex has a good influence on the values of harvest and its quality [15]. This system provides application of various elements of biologization of agriculture, one of which is the sowing of ground cover crops. The effect and aftereffect of different cover crops on soil fertility indicators and crop yields has been studied not enough, and in the conditions of the Crimea, such researches haven't been conducted.

\section{Materials and methods}

The stationary crop rotation for conducting these researches was introduced in 2017. The early results with the possibility to analysis of variance and statistical processing were received in 2018 and 2019.

On the experimental field of the Academy of life and environmental sciences was based 2 experiments with one element for each one in three-time repetition on the cultivation of ground cover crops in no-till system in intermediate crops after harvesting winter wheat and winter barley. Cultivation of winter wheat and winter barley was carried out in 4 complete crop rotations with the following alternation of crops: 
1) peas

2) winter wheat + intermediate crops (cover crops)

3) corn

4) winter barley

Winter wheat Nador and winter barley Luran were sown annually during 1-2 days of October with norm of 2.2-2.5 million pieces/ha.

Peas Pharaon was sown in the 2-3 decade of March with norm 1, 2 million pieces/ha.

The sowing of the above crops in crop rotation on the experimental field was carried out using the seeder G-114 - a direct seeder seeding production of the Gerardi plant (Argentina).

Corn (Berta hybrid) was sown annually on April 25 with the norm 60 thousand pieces/ha using the seeder Sigma 5 (Italy).

Experiment 1. The study of the influence of cover crops was conducted in crop rotation link: winter wheat-corn (in crop sowing after harvesting wheat).

Experience options:

Option 1: no-till system + Winter Rye stubble ground cover seeding

Option 2: no-till system + Winter Rape stubble ground cover seeding

Option 3: no-till system + Winter Vicia stubble ground cover seeding

Option 4: no-till system + Winter Rye + Winter Rape stubble ground cover seeding

Option 5: no-till system + Winter Rye + Vicia stubble ground cover seeding

Option 6: no-till system + Winter Rape + Vicia stubble ground cover seeding

Option 7: no-till system + Winter Rye + Winter Rape + Vicia stubble ground cover seeding

Option 8: no-till system + Oats stubble ground cover seeding

Option 9: no-till system + Radish stubble ground cover seeding

Option 10: no-till system + Oats + Radish stubble ground cover seeding

Option 11: no-till system + Oats + Vicia stubble ground cover seeding

Option 12: no-till system + Radish + Vicia stubble ground cover seeding

Option 13: no-till system + Oats + Radish + Vicia stubble ground cover seeding

Option 14: no-till system + stubble ground cover seeding mixture of 5 crops (corn + pea + flax + sunflower + millet $)$

Option 15: no-till + stubble ground cover seeding mixture of 8 crops $($ corn + peas + flax + sunflower + millet + radish + mustard + vicia)

Option 16: no-till system + stubble ground cover seeding mixture of 11 crops (corn + peas + flax + sunflower + millet + radish + mustard + vicia + switchgrass + lentils + buckwheat)

Option 17: no-till system + stubble ground cover seeding mixture of 13 crops (corn + peas + flax + sunflower + millet + radish + mustard + vicia + switchgrass + lentils + buckwheat + oats + melilot)

Option 18: no-till system without stubble ground cover seeding (control - №1)

Option 19: Traditional soil treatment system without stubble ground cover seeding (control - № 2)

The area of the experimental section (one crop rotation field) is 1,5 hectares.

The area of the elementary plot is $150 \mathrm{~m}(25 \mathrm{~m} \times 6 \mathrm{~m})$

Experiment 2. The study of the cover crops influence was conducted in crop rotation link: winter barley-peas (in crop sowing after harvesting barley). Experience options completely duplicate the scheme presented in experiment № 1 .

In 2018 in the foothill-steppe zone of Crimea after the harvesting winter crops for grain (wheat, barley) from the third decade of June till the first decade of September $188.5 \mathrm{~mm}$ of precipitation fell. This amount of precipitation exceeds the rate of $30-80 \mathrm{~mm}$, which is necessary for ground cover crops growing. The experimental plots were sown on July 3 
after winter wheat harvesting. In 2019 after harvesting winter crops for grain (wheat, barley) from the third decade of June till the first decade of September $166.9 \mathrm{~mm}$ of precipitation fell. Experimental plots of land after winter barley harvesting were sown on July 2, after winter wheat - on July 17.

In 2019 groundcover crops have been growing in the Field № 25 (after wheat) and in the Field № 22 (after barley). Winter barley Luran variety was sown on October 19 in 2018 with a norm of 2.25 million pieces ha. The predecessor was corn. Due to heavy rainfall and hail on June 5, 2019, the greatest yield losses were on the field of winter barley Luran variety. The winter barley's windfall which sprang up in a short time, created serious competition both for cultivated plants and weeds.

The barley harvest was carried out on June 22 by the Terion combine. The grain yield was $23 \mathrm{C} /$ ha. On June 25 the field was processed with the mixture of glyphosate (360) 3 1/ha + Esteron $300 \mathrm{~g}+$ Adyu adhesive (100 $\mathrm{g}$ for every 100 liters of water).

After the winter wheat harvesting and 5 days before the sowing of intermediate crops the field was also processed with the mixture of glyphosate (360) 3 1/ha + Esteron $300 \mathrm{~g}+$ Adyu adhesive (100 g for every 100 liters of water)

\section{Results and discussion}

The basic indicators of soil structure are density and porosity. Soil density plays a big role for good development of the agricultural crops root system. In its turn agricultural crops with fibrous root system can improve the soil structure. In general for the favorable development of the root crops system the soil density of the arable layer should be in the range of $1.10 \mathrm{~g} / \mathrm{cm}^{3}$ to $\mathrm{g} / \mathrm{cm}^{3}$ (up to $1.40 \mathrm{~g} / \mathrm{cm}^{3}$ for tilled crops). In our researches on average for 2 years (2018 and 2019) soil density of arable layer $(0-30 \mathrm{~cm})$ was in the optimal range - from $1.18 \mathrm{~g} / \mathrm{cm}^{3}$ (under oilseed radish) up to $1.28 \mathrm{~g} / \mathrm{cm}^{3}$ (under oats, radish and vicia in the mix), at the same time the difference between options with intermediate soil cover crops and without them was not significant $\left(\mathrm{F}_{\mathrm{v}}<\mathrm{F}_{05(\mathrm{v})}\right)$.

The second key indicator of soil structure is general porosity, which shows the total volume of all pores. These pores may be filled with air and water. When the number of them is optimal (55-65\%), the normal processes as movement, accumulation and preservation of soil moisture, as well as the exchange of air proceed as usual. In our researches on average for 2 years the optimal number of pores in the arable layer was observed only on three options of ground cover crops - winter rape + vicia $(55.0 \%)$, oilseed radish $(56.2 \%)$ and the mixture of five crops (55.6\%): corn+peas+flax+sunflower+lentils. Along with that the total porosity of all considered options was $4,5 \%$ higher on average in the upper soil layer 0-10 cm compared to the lower layer $10-30 \mathrm{~cm}$.

One more indicator of soil structure is porosity aeration, which shows the amount of pores where the exchange between soil air and atmospheric air is running. This is very important process for the activity of aerobic microorganisms. The good air exchange happens when aeration is porous more than $20 \%$. In our esearches all explored intermediate ground cover crops the porosity aeration of the arable layer are in the optimal value: from $35.4 \%$ (under winter rape) to $42.6 \%$ (under winter rape with vicia).

The small capillary pores which are less than $0.1 \mathrm{~mm}$ in size play an important role in the accumulation and preservation of moisture. Their quantity must be equal to the large non-capillary pores, but this condition is optimal for an area with sufficient moisture. In dry areas the number of capillary pores should be more than 1.5-2 times regarding noncapillary. In our surveys on average for 2 years the most optimal proportion of capillary and non-capillary pores were formed under a single-species vicia seeding, oats and radishes, as well as under a mixture of oats, radish and vicia; less optimal proportion was formed under winter rape, both in its pure form and in a mixture with vicia. In the option with a five- 
component mixture, as well as under the control (without intermediate ground cover crops) the number of capillary pores exceed non-capillary ones by 2.2 times. The lack of larger non-capillary pores can lead to deterioration of water permeability, and therefore to loss of moisture.

Moisture is a limiting factor which restricts receiving high and stable harvest in the Republic of Crimea. During the high-draught periods (July-September) is very important to save moisture not only in the seed layer of the soil to obtain good shoots of winter crops and their favorable overwintering but also in the meter layer of soil.

On average over 2 years the available moisture reserves did not significantly varied by different options of intermediate soil cover crops (table 1). However according to A.A.Rode, the reserves of available moisture in the meter layer, which are locatedat the level of 90-130 $\mathrm{mm}$ are considered as satisfactory. Such reserves were only in the option with vicia - 107,6 $\mathrm{mm}$ and under the control (without ground cover crops) the available moisture for plants was in the options with winter rape, both pure $(59.3 \mathrm{~mm})$ and mixed with vicia $(44.9 \mathrm{~mm})$. A.A.Rode is considered such reserves as very bad $(<60 \mathrm{~mm})$.

Table 1. Reserves of available moisture in the soil under the ground cover crops in September, mm (average for 2018-2019).

\begin{tabular}{|l|c|c|c|c|}
\hline \multirow{2}{*}{\multicolumn{1}{|c|}{ Option }} & \multicolumn{4}{c|}{ Soil layer. $\mathbf{~ c m ~}$} \\
\cline { 2 - 5 } & $\mathbf{0 - 2 0}$ & $\mathbf{0 - 5 0}$ & $\mathbf{5 0 - 1 0 0}$ & $\mathbf{0 - 1 0 0}$ \\
\hline №2 Winter rape & 12.2 & 32.1 & 27.2 & 59.3 \\
\hline №3 Winter vicia & 22.6 & 49.9 & 57.8 & 107.6 \\
\hline №6 Winter rape + vicia & 18.2 & 28.9 & 16.0 & 44.9 \\
\hline №9 Radish & 20.4 & 45.5 & 31.4 & 76.9 \\
\hline №10 Oats + Radish & 23.4 & 51.1 & 35.0 & 86.0 \\
\hline №13 Oats + Radish + vicia & 19.0 & 45.9 & 30.5 & 76.4 \\
\hline $\begin{array}{l}\text { №14 Corn + pea + flax + sunflower + } \\
\text { lentil }\end{array}$ & 17.2 & 41.8 & 33.0 & 74.8 \\
\hline №18 without cover crop (control) & 24.4 & 59.8 & 39.9 & 99.6 \\
\hline \multicolumn{1}{|c|}{ SSD } & $\mathrm{F}_{\mathrm{V}}<\mathrm{F}_{05}(\mathrm{~V})$ & $\mathrm{F}_{\mathrm{V}}<\mathrm{F}_{05}(\mathrm{~V})$ & $\mathrm{F}_{\mathrm{V}}<\mathrm{F}_{05}(\mathrm{~V})$ & $\mathrm{F}_{\mathrm{V}}<\mathrm{F}_{05}(\mathrm{~V})$ \\
\hline
\end{tabular}

In the other explored options the available moisture reserves in the meter layer of soil were at the level of 74.8-86.0 mm, which are bad reserves.

The basis of favorable agrophysical characteristics of the soil is an agronomically valuable structure - the soil particles sized from 0.25 to $10 \mathrm{~mm}$ in diameter.

In our surveys (in 2019) the macrostructure the arable layer of soil $(0-30 \mathrm{~cm})$ differed significantly depending on the intermediate ground cover crops. A good soil structure was formed in 4 studied areas options (table 2): № 4 winter rye + winter rape $(61.9 \%)$, № 6 winter rape + winter vicia $(59.5 \%)$, №12 radish + vicia $(59.8 \%)$ and №13 oats + radish + vicia $(62.2 \%)$; unsatisfactory soil structure was formed in options №1 with winter rye (42.3\%), №10 with oat and radish (42\%), №16 with a mixture of 10 cultures (45.8\%) and control 2 (№ 19) with a traditional farming system (48.2\%) with SSD $_{05} 11.4$. In other studied options the structure of the soil of the arable layer was satisfactory (51.0-58.4\%).

Table 2. Macrostructure of the arable soil layer $(0-30 \mathrm{~cm}), 2019$.

\begin{tabular}{|c|c|}
\hline Option & Macrostructure, \% \\
\hline 1 & 42.3 \\
\hline 2 & 54.4 \\
\hline 3 & 58.0 \\
\hline 4 & 61.9 \\
\hline 5 & 58.1 \\
\hline
\end{tabular}




\begin{tabular}{|c|c|}
\hline 6 & 59.5 \\
\hline 7 & 55.4 \\
\hline 8 & 54.3 \\
\hline 9 & 55.0 \\
\hline 10 & 42.0 \\
\hline 11 & 60.2 \\
\hline 12 & 59.8 \\
\hline 14 & 62.2 \\
\hline 15 & 56.7 \\
\hline 16 & 51.0 \\
\hline 17 & 45.8 \\
\hline 18 & 52.3 \\
\hline SSD $_{05}$ & 58.4 \\
\hline
\end{tabular}

In general we can note that for 2 years of research significant differences in the effect of different variants of intermediate ground cover crops on the agro-physical soil properties were not observed. This is connected with the fact that the data of the research was conducted during the transition period from the traditional farming system to the no-till system. For more truthful conclusions it is necessary to continue the conducting of research in this area for at least 5 years.

On average for 2 years the highest yield of soil cover crops (an indicator that characterizes the volume of biomass entering the soil and used in the future for reproduction of fertility) during the growing hem after winter wheat was received in the options for seeding the mixtures of 5, 8 and 10 components - №14, 15 and 16 (from 10.8 till $12.2 \mathrm{t} / \mathrm{ha})$. The lowest yield was received on the plot number 1 . - winter rye $(1.2 \mathrm{t} / \mathrm{ha})$. Along with that according to the results of the dispersion analysis of the given yield's data for average of 2 years leveled are leveled (table 3 ). This is connected with large fluctuations of this indicator each year because of the different weather conditions. Thus in 2018 maximum precipitation period was July month, when all the experiments seeds had already been sown, and in 2019 the maximum amount of summer rain fell in June, what prevented sowing in the shortest possible time while free moisture did not evaporate from the top layer. But for each particular year in section of plots using different crops as the influence on their productivity was noted for groundcovers.

Taking into account for the yield on plots with ground cover crops in 2018 was held on August 19. 4 days later on August 23 the shoots were treated with a Roundup in order to stop their vegetation and weed vegetation. Among the options with winter crops as ground cover crops the maximum yield of the green mass is marked in option №4 winter rye with winter rape (7.2 t/ha), among the spring crops - option №10 oats with radish (5.6 t/ha of green mass). The maximum yield of the green mass of cultivated crops, in total from the experience was formed in the option №14 a mixture of 5 cover crops (corn + peas + flax + sunflower + lentils) -13.9 t/ha.

The received harvest in 2019 on groundcover crops after winter barley was counted on September 28, and after winter wheat - on October 10. In 2019 the treatment of ground cover crops with herbicide to stop their vegetation was not conducted, because of the lack of weeds that exceed the ELH (Economic Limit of Harmfulness).

Table 3. The yield of groundcover crops (after winter wheat), c/ha.

\begin{tabular}{|c|c|c|c|}
\hline Option & 2018 year & 2019 year & On average for 2 years \\
\hline 1 & 6.4 & 18.4 & 12.4 \\
\hline 2 & 33.9 & 27.2 & 30.6 \\
\hline 3 & 30.6 & 3.4 & 17.0 \\
\hline
\end{tabular}




\begin{tabular}{|c|c|c|c|}
\hline 4 & 72.0 & 33.6 & 52.8 \\
\hline 5 & 15.3 & 7.2 & 11.3 \\
\hline 6 & 36.3 & 24.8 & 30.6 \\
\hline 7 & 26.2 & 18.4 & 22.3 \\
\hline 8 & 31.6 & 65.4 & 48.5 \\
\hline 9 & 38.1 & 62.4 & 50.3 \\
\hline 10 & 56.5 & 58.0 & 57.3 \\
\hline 11 & 33.4 & 52.6 & 43.0 \\
\hline 12 & 35.1 & 50.3 & 42.7 \\
\hline 13 & 28.8 & 82.0 & 55.4 \\
\hline 14 & 139.3 & 103.1 & 121.2 \\
\hline 15 & 42.8 & 201.6 & 122.2 \\
\hline 16 & 27.8 & 188.8 & 67.3 \\
\hline 17 & 48.7 & 86.4 & 52.5 \\
\hline $\begin{array}{c}\text { Average from the } \\
\text { experience }\end{array}$ & 41.3 & 63.7 & $\mathrm{~F}_{\mathrm{V}}<\mathrm{F}_{05}(\mathrm{~V})$ \\
\hline SSD 05 & 11.2 & 28.8 & \\
\hline
\end{tabular}

Thus in 2019 among the options with winter crops as groundcover the yield of green mass was the maximum at the level of $3.3 \mathrm{t}$ /ha in option №4 (rye with rape). Among spring crops variants of sowing one and 2 crops provided a yield of green mass at the level of 5.0 $-6.5 \mathrm{t} / \mathrm{ha}$, the difference between them did not exceed $\mathrm{SSD}_{05} \mathrm{t}=2.88 \mathrm{t} / \mathrm{ha}$. The threecomponent mixture (plot № 13 - Oats + Radish+ Vicia) due to the best interaction of plants in the agrophytocenosis provided the yield of $8.2 \mathrm{t} / \mathrm{ha}$, which is 3-3. $2 \mathrm{t}$ higher than in 11 and 12 options at $\mathrm{SSD}_{05}=2.9 \mathrm{t}$. Multicomponent mixtures of 5, 8 and 10 crops provided yields of 10.9, 20.3 and 19.6 t/ha, respectively. The maximum yield of the green mass, both among multicomponent mixtures, and in general from the experience was formed in the option 15 - a mixture of 8 crops of stubble (corn+ peas+ flax+ sunflower+ radish+ mustard+ lentils+ buckwheat) $-20.3 \mathrm{t} / \mathrm{ha}$, while the maximum weight of the green mass was provided by sunflower and rare oilseeds.

According to experiment № 2 after the winter barley on average during the years of research the maximum yield of the green mass of groundcover crops (from 4.9 to $6.9 \mathrm{t} / \mathrm{ha}$ ) was noted in the options using multicomponent mixtures (№15, 16, 17), which was 2 times higher than the yield of intermediate groundcover crops from 1-2 and 3 spring crops (table 4).

Table 4. The yield of groundcover crops (after winter barley), c/ha.

\begin{tabular}{|c|c|c|c|}
\hline Option & 2018 year & 2019 year & $\begin{array}{c}\text { On average for 2 } \\
\text { years }\end{array}$ \\
\hline 9 & 24.2 & 52.4 & 31.0 \\
\hline 11 & 44.6 & 14.9 & 37.6 \\
\hline 12 & 18.1 & 27.5 & 21.1 \\
\hline 15 & 66.1 & 42.4 & 61.3 \\
\hline 16 & 48.1 & 48.6 & 49.0 \\
\hline 17 & 76.5 & 45.8 & 69.5 \\
\hline Average from the experience & 46.3 & 38.6 & 44.9 \\
\hline SSD $_{05}$ & 8.8 & 8.3 & 26.6 \\
\hline
\end{tabular}

Moreover, according to option № 17 (a mixture of 12 crops) the yield was maximum annually regardless of weather and climatic conditions.

The records of weeds in all options of the experiment, determined by the quantitativeweight method showed that in 2019 as the proportion and mass of weeds greatly decreased compared to the previous 2018 and had an inversely proportional dependence on the yield of green mass grown cover crops. On the control plot without ground cover crops $3.6 \mathrm{t} / \mathrm{ha}$ 
of green mass was formed during the summer period, including $38.1 \%$ (1.38 t/ha) of winter crop windfall.

Parallel studies conducted in another laboratory showed that by the end of the growing season of spring crops, $30-33 \mathrm{~kg}$ of nitrogen, $4-5.9 \mathrm{~kg}$ of phosphorus, and $13.9-16.7 \mathrm{~kg}$ of potassium were accumulated in plants and in the root system per hectare (table 5).

Table 5. The content of the main elements (nitrogen, phosphorus and potassium) accumulated by the vegetative organs of plants and their root system during the growing season, $\mathrm{kg} / \mathrm{ha}$.

\begin{tabular}{|c|c|c|c|c|c|}
\hline \multirow{2}{*}{ № } & \multirow{2}{*}{\multicolumn{2}{|c|}{ The title of hybrid }} & \multicolumn{3}{|c|}{ Real content. kg / ha } \\
\hline & & & \multirow{2}{*}{$\begin{array}{c}\text { Nitrogen } \\
1.1\end{array}$} & \multirow{2}{*}{$\begin{array}{c}\text { Phosphorus } \\
0.2\end{array}$} & \multirow{2}{*}{$\begin{array}{c}\text { Potassium } \\
0.4\end{array}$} \\
\hline \multirow{13}{*}{ №15 } & \multirow[t]{2}{*}{ Corn } & $\begin{array}{c}\text { Vegetative } \\
\text { mass }\end{array}$ & & & \\
\hline & & Roots & 1.0 & 0.2 & 0.5 \\
\hline & \multirow{2}{*}{ Peas } & $\begin{array}{l}\text { Vegetative } \\
\text { mass }\end{array}$ & 1.2 & 0.1 & 0.2 \\
\hline & & Roots & 0.3 & 0.0 & 0.1 \\
\hline & \multirow{2}{*}{ Sunflower } & $\begin{array}{l}\text { Vegetative } \\
\text { mass }\end{array}$ & 10.0 & 2.0 & 5.3 \\
\hline & & Roots & 1.6 & 0.5 & 0.4 \\
\hline & \multirow[t]{2}{*}{ Flax } & $\begin{array}{c}\text { Vegetative } \\
\text { mass }\end{array}$ & 3.6 & 0.4 & 0.7 \\
\hline & & Roots & 0.6 & 0.1 & 0.4 \\
\hline & \multirow[t]{2}{*}{ Mustard } & $\begin{array}{c}\text { Vegetative } \\
\text { mass }\end{array}$ & 7.7 & 1.0 & 1.4 \\
\hline & & Roots & 0.3 & 0.0 & 0.1 \\
\hline & \multirow[t]{2}{*}{ Radish } & $\begin{array}{c}\text { Vegetative } \\
\text { mass }\end{array}$ & 4.8 & 0.8 & 3.5 \\
\hline & & Roots & 0.9 & 0.2 & 0.8 \\
\hline & Total from th & (2019 year) & 33.11 & 5.871 & 13.90 \\
\hline \multirow{5}{*}{ №10 } & \multirow[t]{2}{*}{ Radish } & $\begin{array}{c}\text { Vegetative } \\
\text { mass }\end{array}$ & 20.23 & 3.26 & 14.19 \\
\hline & & Roots & 7.08 & 0.64 & 0.48 \\
\hline & \multirow[t]{2}{*}{ Oat } & $\begin{array}{c}\text { Vegetative } \\
\text { mass }\end{array}$ & 3.25 & 0.31 & 1.68 \\
\hline & & Roots & 0.42 & 0.10 & 0.319 \\
\hline & \multicolumn{2}{|c|}{ Total from the plot (2018 year) } & 30.9 & 4.3 & 16.7 \\
\hline
\end{tabular}

In 2019 soil samples were selected to determine the content of available forms of basic nutrients on plots after cultivation of ground cover crops before sowing corn. These data are presented in table 6 .

Table 6. The results of agrochemical survey of the soil in the layer of $0-30 \mathrm{~cm}$ after cultivation of ground cover crops (March 2019).

\begin{tabular}{|l|c|c|c|}
\hline \multicolumn{1}{|c|}{ Option's content } & $\begin{array}{c}\mathbf{P}_{2} \mathbf{O}_{\mathbf{5}} \\
\mathbf{m g} / \mathbf{k g}\end{array}$ & $\begin{array}{c}\mathbf{K}_{\mathbf{2}} \mathbf{O .} \\
\mathbf{m g} / \mathbf{k g}\end{array}$ & $\begin{array}{c}\text { Organic } \\
\text { matter. \% }\end{array}$ \\
\hline 18. no-till + without cover crop & 45.8 & 211.4 & 3.13 \\
\hline 19. The traditional tillage system without a cover crop & 48.1 & 187.3 & 3.12 \\
\hline 3. no-till + winter cover vicia & 51.6 & 232.0 & 3.16 \\
\hline 4. no-till + winter cover rye + winter rape & 65.6 & 294.7 & 3.32 \\
\hline 5. no-till + winter cover rye + vicia & 65.8 & 220.7 & 3.38 \\
\hline 6. no-till + winter cover rape + vicia & 54.9 & 198.7 & 3.57 \\
\hline 7. no-till + winter cover rye + rape+ vicia & 47.4 & 207.0 & 3.21 \\
\hline 8. no-till + cover oat & 26.8 & 160.7 & 2.83 \\
\hline 9. no-till + cover radish & 38.2 & 212.3 & 3.06 \\
\hline 10. no-till + cover oat + radish & 49.2 & 215.3 & 3.23 \\
\hline
\end{tabular}




\begin{tabular}{|l|c|c|c|}
\hline 11. no-till + cover oat + vicia & 31.5 & 196.3 & 2.91 \\
\hline 12. no-till + cover radish + vicia & 36.6 & 203.3 & 2.95 \\
\hline 13. no-till + cover oat + radish + vicia & 45.9 & 213.3 & 2.91 \\
\hline 14. no-till + cover (corn+pea+flax+sunflower+lentil) & 47.9 & 250.0 & 3.07 \\
\hline SSD $_{05}$ & 5.43 & 20.4 & $0.18 \%$ \\
\hline
\end{tabular}

The conducted agrochemical survey of soil samples showed that the studied soil treatment systems, both traditional and no-till systems, provided a close influence on the content of the main indicators, namely the content of $\mathrm{P}_{2} \mathrm{O}_{5}, \mathrm{~K}_{2} \mathrm{O}$ and organic matter on an average of $0-30 \mathrm{~cm}$ of the soil layer. It should be noted that in the section on soil layers 0 $10,10-20$ and $20-30 \mathrm{~cm}$ there is a clear differentiation of higher content of phosphorus, potassium and humus in the upper $0-10 \mathrm{~cm}$ layer of soil in the no-till system. This is due to the fact that in the traditional system of tillage in the crop rotation where along with shallow and surface tillage, deep ploughing is carried out to a depth of $30 \mathrm{~cm}$, as a result of mixing the soil layers, their uniform distribution occurs and in the no-till system only the upper $0-10 \mathrm{~cm}$ layer of soil is exposed to mechanical tools (turbo disk and double disk).

In comparison with the control the studied options had different effects on the accumulation of $\mathrm{P}_{2} \mathrm{O}_{5}, \mathrm{~K}_{2} \mathrm{O}$ and organic matter in the soil. The best results for the content of $\mathrm{P}_{2} \mathrm{O}_{5}$ in the soil were provided by the combination of the no-till system with sowing of cover mixtures of winter rye with winter rape $(65.6 \mathrm{mg} / \mathrm{kg})$ or vicia $(65.8 \mathrm{mg} / \mathrm{kg})$ at $\mathrm{SSD}_{05}=5.43 \mathrm{mg} / \mathrm{kg}$ (table 6). At the same time the combination of all three crops in cover sowing reduced the $\mathrm{P}_{2} \mathrm{O}_{5}$ to the control's level $(47.4$ contrary to $45.8 \mathrm{mg} / \mathrm{kg}$ under the control). The similar results were received for the content of $\mathrm{K}_{2} \mathrm{O}$ and organic matter. Thus the sowing of winter cover crops (vicia, rye, rape) after winter wheat provided the greatest accumulation of easily accessible forms of $\mathrm{P}_{2} \mathrm{O}_{5}, \mathrm{~K}_{2} \mathrm{O}$ and organic matter in the soil.

The using of spring crops as cover crops did not provide a significant difference in the learned indicators. The option with a cover crop of oats $(26.8 \mathrm{mg} / \mathrm{kg})$ and radish $(38.2$ $\mathrm{mg} / \mathrm{kg}$ ) was the poorest in terms of P2O5 availability. In comparison with the control the decrease of $\mathrm{P}_{2} \mathrm{O}_{5}$ in these options was 41.5 and $16.6 \%$, respectively.

In terms of potassium content the only one option provided a significant increase of $\mathrm{K}_{2} \mathrm{O}$ in the soil - a mixture of 5 crops: corn, peas, flax, sunflower and lentils. This is explained by fact that these plants during their growth and development accumulate a significant amount of potassium in by-products, which subsequently after their decomposition in the soil, provides a significant replenishment of $\mathrm{K}_{2} \mathrm{O}$ in the soil.

The yield of an early-ripening hybrid of Berta corn (Kabardino-Balkarian Republic) grown after the studied groundcover crops varied greatly over the years from 22 to 33.8 $\mathrm{c} / \mathrm{ha}$ and is presented in table 7.

In 2018 the average yield of corn was 2.2 t/ha and in $2019-3.4$ t/ha. This is directly related to the conditions of humidification of the year. Despite the fact that during the corn vegetation season (from May to September) in 2018 - $220 \mathrm{~mm}$ of precipitation fell, and in $2019-187 \mathrm{~mm}$, they differed in timing of precipitation and intensity. Thus, in 2018 only 4 $\mathrm{mm}$ of precipitation fell in April, which did not provide the appearance of friendly shoots and the following rainfall that fell in July $(149 \mathrm{~mm})$ did not have a significant impact on the formation of cobs, because they were in the phase of milk and milk-wax ripeness. In 2019 $29 \mathrm{~mm}$ of precipitation fell during the month of April, which guaranteed timely and friendly corn shoots 8 days after sowing. Further the highest amount of precipitation fell in June (85 $\mathrm{mm}$ ) and August (52 mm).

Table 7. The yield of corn hybrid Bertha, c/ha.

\begin{tabular}{|c|c|c|c|}
\hline Option & 2018 year & 2019 year & On average for 2 years \\
\hline 1 & 29.0 & 29.8 & 29.4 \\
\hline 2 & 23.2 & 36.1 & 29.7 \\
\hline
\end{tabular}




\begin{tabular}{|c|c|c|c|}
\hline 3 & 18.1 & 35.9 & 27.0 \\
\hline 4 & 20.0 & 33.6 & 26.8 \\
\hline 5 & 13.4 & 42.1 & 27.8 \\
\hline 6 & 26.1 & 35.2 & 30.7 \\
\hline 7 & 21.8 & 27.3 & 24.6 \\
\hline 8 & 16.3 & 26.6 & 23.1 \\
\hline 9 & 15.6 & 32.4 & 24.0 \\
\hline 10 & 20.5 & 32.4 & 26.5 \\
\hline 11 & 20.0 & 27.7 & 23.9 \\
\hline 12 & 23.1 & 35.7 & 29.4 \\
\hline 13 & 20.3 & 29.6 & 25.0 \\
\hline 14 & 21.4 & 35.6 & 28.5 \\
\hline 15 & 24.5 & 34.6 & 29.6 \\
\hline 16 & 27.3 & 30.1 & 28.7 \\
\hline 17 & 28.3 & 25.7 & 27.0 \\
\hline 18 & 21.1 & 47.3 & 34.2 \\
\hline 19 & 28.2 & 43.5 & 35.9 \\
\hline $\begin{array}{c}\text { Average from the } \\
\text { experience }\end{array}$ & 22.0 & 33.8 & 28.0 \\
\hline $\mathrm{SSD}_{05}$ & 4.3 & $\mathrm{~F}_{\mathrm{V}}<\mathrm{F}_{05(\mathrm{~V})}$ & $\mathrm{F}_{\mathrm{V}}<\mathrm{F}_{05(\mathrm{~V})}$ \\
\hline
\end{tabular}

The highest yield of corn in 2018 (2.8 t/ha) and on average for 2 years $(3.6 \mathrm{t} / \mathrm{ha})$ was formed according to the option №19 - the Traditional system of soil treatment without ground cover seeding (the control - № 2) with the use of the plowing without turning over the top layer of the earth at $22-24 \mathrm{~cm}$ from autumn. At the same time in 2018 the same yield as in the control area (the difference did not exceed $\mathrm{SSD}_{05}=4.3$ ) was received in the options after growing multicomponent spring crop mixtures as groundcover crops: options № 15 (8 crops), № 16 (10 crops) and № 17 (12 crops) with a yield of $2.4 ; 2.7$ and 2.8 , respectively.

In 2019 and on average for 2 years of research the difference in yield depending on the cultivation of ground cover crops was not found.

In the first 2 years when transition from traditional farming to the no-till system because of the high degree of potential contamination we witnessed an active growth of weeds in our plots. At the same time the structure and the quantity of weeds and their vegetative mass directly depended on the crops that were grown as ground cover crops. Thus, after winter wheat in the transition year 2018 during the sowing winter crops and their mixtures, the option 4 (winter rye + winter rape) gave the maximum mass of cultivated plants -72.0 $\mathrm{c} / \mathrm{ha}$ and the minimum mass of weeds $-21.5 \mathrm{c} / \mathrm{ha}$, so the mass of cultivated plants was 3.3 times higher than mass of weeds (figure 1). Meanwhile, the number of cultivated plants was not the maximum - $45.3 \mathrm{pcs} / \mathrm{m}^{2}$ (while $49.0-114,7 \mathrm{pcs} / \mathrm{m} 2$ in other options with winter crops). But in this option the number of weeds was minimal $-16.7 \mathrm{pcs} / \mathrm{m}^{2}$ (2.7 times less) than the cultivated plants, which indicates the greatest alellopathic ability in mixed cultivation of winter rye and rape in comparison with other options, so sowing in a monoculture of rape and rye as well as adding winter vicia to such a mixture are not able to provide maximum competitiveness compared to a two-component mixture. In this option № 4 the main types of weeds were grass (Poaceae) and field bindweed (Convolvulus arvensis). 


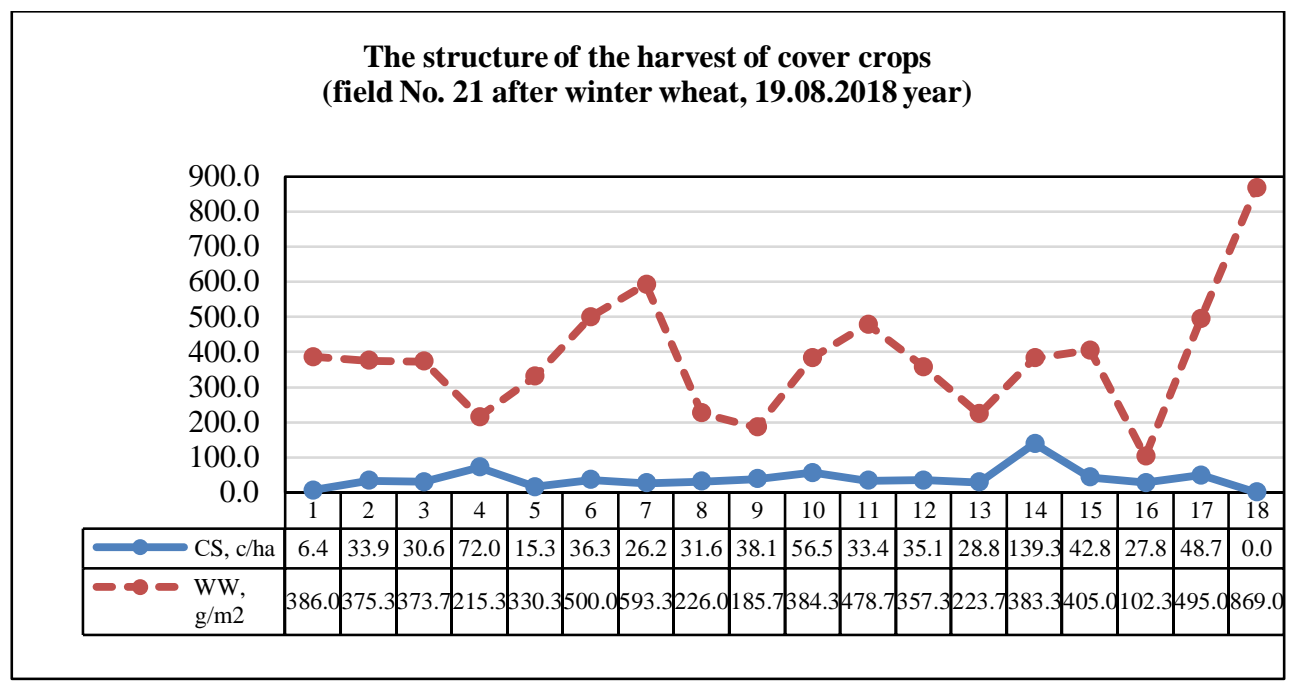

Fig. 1. The weight of cultivated crops and weeds during the growing of intermediate groundcover crops in the winter wheat-corn crop rotation link.

In the control option № 18 (without cover crops) the fresh mass of weeds was $86.9 \mathrm{c} / \mathrm{ha}$ $\left(111.3 \mathrm{pcs} / \mathrm{m}^{2}\right)$ - one of the maximum indicators, which is explained by the lack of competition from any cultivated plants, that provided the ideal conditions for the growth and development of weeds. There were 64 pieces $/ \mathrm{m}^{2}$ - Poaceae, 12 Cirsium arvense, 9 Portulaca oleracea, 17 Convolvulus arvensis, 6 Amaranthus retrofléxus, 3 Euphorbia. In other options the number of weeds significantly decreased at $\mathrm{SSD}_{05}=44.2$.

There was no competition for weeds and the plots with mixed crops of rape and vicia plot № 6 - 226,7 pcs $/ \mathrm{m}^{2}$ with the largest part was occupied by cereal weeds and wheat winfall (Poaceae), the total number of which was $245 \mathrm{pcs} / \mathrm{m}^{2}$, there were also 2 Sonchus arvensis, 16 Atriplex and 8 Portulaca oleracea.

Despite the fact that among such spring crops as oats, radish and vicia the largest mass of cultivated plants $-56.5 \mathrm{c} / \mathrm{ha}$ - was noted on the option number 10 oats + radish, but this option did not provide the maximum suppression of weeds. And the highest competition for weeds was made by mono-sowing of oilseed radish (option №9), where the mass of weeds was 2 times less than the mass of cultivated plants. The lowest competition for weeds in the formation of green mass was made by plants in the option of experiment № 11 - oats +vicia (the mass of weeds was 1.4 times higher than the mass of the cultural mixture).

During the analysis of the quantitative indicators of grown plants on plots with spring crops, we found that the largest number of cultivated plants was also in option 10 (oats + radish) - $120.7 \mathrm{pcs} / \mathrm{m}^{2}$, where there were 65 plants of oats and 56 plants of radishes, which is significantly higher than the other options, with the $\mathrm{SSD}_{05}$ equal to 23.1. The lowest number of cultivated plants was noted in option 13 (oats + radish + vicia) and in variant №9 (radish), where their number was at the level of $68.3-77.3 \mathrm{pcs} / \mathrm{m}^{2}$, respectively. However, according to quantitative indicators the smallest number of weeds was noted in variant №12 (radish + vicia) - $31.8 \mathrm{pcs} / \mathrm{m} 2$, where 18 cereal grains (Poaceae), 8 Sonchus arvensis, 3 Convolvulus arvensis, 3 Atriplex.

Among the multicomponent (5-13 crops) mixtures in the transition year 2018 we noted the most productive as for weight of the green mass plot № 14 (a mixture of 5 crops), where the crop yield was $139.3 \mathrm{c} / \mathrm{ha}$. And the number of cultivated plants for harvesting here was the maximum $94.0 \mathrm{pcs} / \mathrm{m} 2$, but this plot was not the best in terms of competitive ability, since the number of weeds was close to the control options of $101.7 \mathrm{pcs} / \mathrm{m}^{2}$ at the control of $111.3 \mathrm{pcs} / \mathrm{m}^{2}$, although the weight of weeds is 3.9 times less than under the 
control $-223.7 \mathrm{~g} / \mathrm{m}^{2}$ at 869.0 under the control (Pic. 2).

And the smallest number of weeds was observed in plots № 15,16 and 17, where weeds were found from 22,0 to $54,3 \mathrm{pcs} / \mathrm{m} 2$. The multi-component mixtures were dominated by Convolvulus arvensis, cereal grains and Sonchus arvensis.

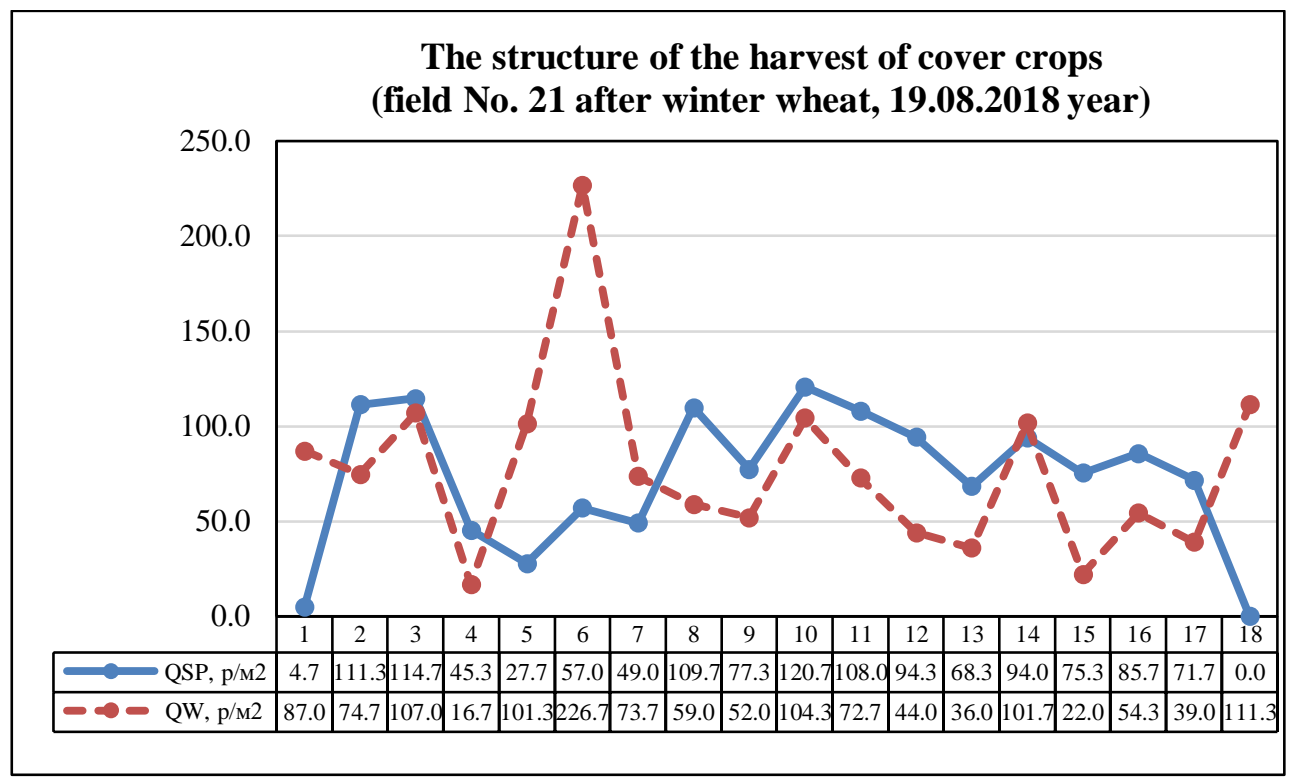

Fig. 2. The number of cultivated crops and weeds during the growing of intermediate groundcover crops in the winter wheat-corn crop rotation link.

It should be marked that after the transition from traditional farming to the no-till system for the third year 2019 there was a sudden decrease in both the number and weight of weeds in intermediate cover crops. So, if under the control in 2019 there were wheat windfall, field bindweed, milkweed, white Mar, pink osot, ragweed and stork cycut, then in plots where ground cover intermediate crops grew mainly as a weed, there were wheat windfall from 24 to $80 \mathrm{pcs} / \mathrm{m}^{2}$ and sometimes field bindweed from 0 to $20 \mathrm{pcs} / \mathrm{m}^{2}$.

Analyzing the structure of yield ground cover crops taking into account the weeds, the predecessor of which was a field of winter barley (in 2018 this field № 24) we accounted the mass of cultural and weed plants, where the highest mass of cultivated plants of winter and spring (1-3 of crops) provided the option number 8 (oats) and $64.9 \mathrm{~kg} / \mathrm{ha}$ (Pic. 3). The lowest figure was in option №2 - (winter rape) - $14.6 \mathrm{c} / \mathrm{ha}$, as well as in options №6 (winter rape + vicia) - 18.4 and №12 (radish +vicia) - $18.1 \mathrm{c} / \mathrm{ha}$, with $\mathrm{SSD}_{05}=7.5 \mathrm{c} / \mathrm{ha}$. Accordingly, when taking into account weeds, we determined the highest mass index of weeds in the option №1 (winter rye) and №2 - (winter Rap) - 71 and 37.7 c/ha, respectively; also in option \#№6 (winter rape + vicia) - 40.1 c/ha; № 12 (radish +vicia) $39.6 \mathrm{c} / \mathrm{ha}$, with $\mathrm{SSD}_{05}=14.4 \mathrm{c} / \mathrm{ha}$, and the lowest weight of weeds was noted in option № 8 (oats) $-12.7 \mathrm{c} / \mathrm{ha}$, which is 5.1 times less than the mass of cultivated plants. And according to the quantitative proportion of cultivated and weed plants, the plot number 8 with oats sown in pure form had an advantage over other options of the experiment. The number of cultivated plants was the maximum $-147.0 \mathrm{pcs} / \mathrm{m}^{2}$ and the minimum weed $-56.3 \mathrm{pcs} / \mathrm{m}^{2}: 2$ ragweed, 2 sedge, 7 bindweed, 15 annual chistets, 30 cereals. Despite the fact that in the 18 control option the mass of weeds was only $23.2 \mathrm{c} / \mathrm{ha}\left(231.7 \mathrm{~g} / \mathrm{m}^{2}\right)$, but the number of weeds the maximum value of all 18 options of the experiment was in this version $-267.3 \mathrm{pcs} / \mathrm{m}^{2}$ (Pic. 4). The largest part of weeds here were cereals (Poaceae) - $100 \mathrm{pcs} / \mathrm{m}^{2}, 90$ - annual chistets (Stachys annua), 72 plants of field bindweed (Convolvulus arvensis), 6 wasp 
(Sonchus arvensis). This maximum amount was obtained due to the lack of cultivated plants, which could provide serious competition for the life (development and growth) of weeds.

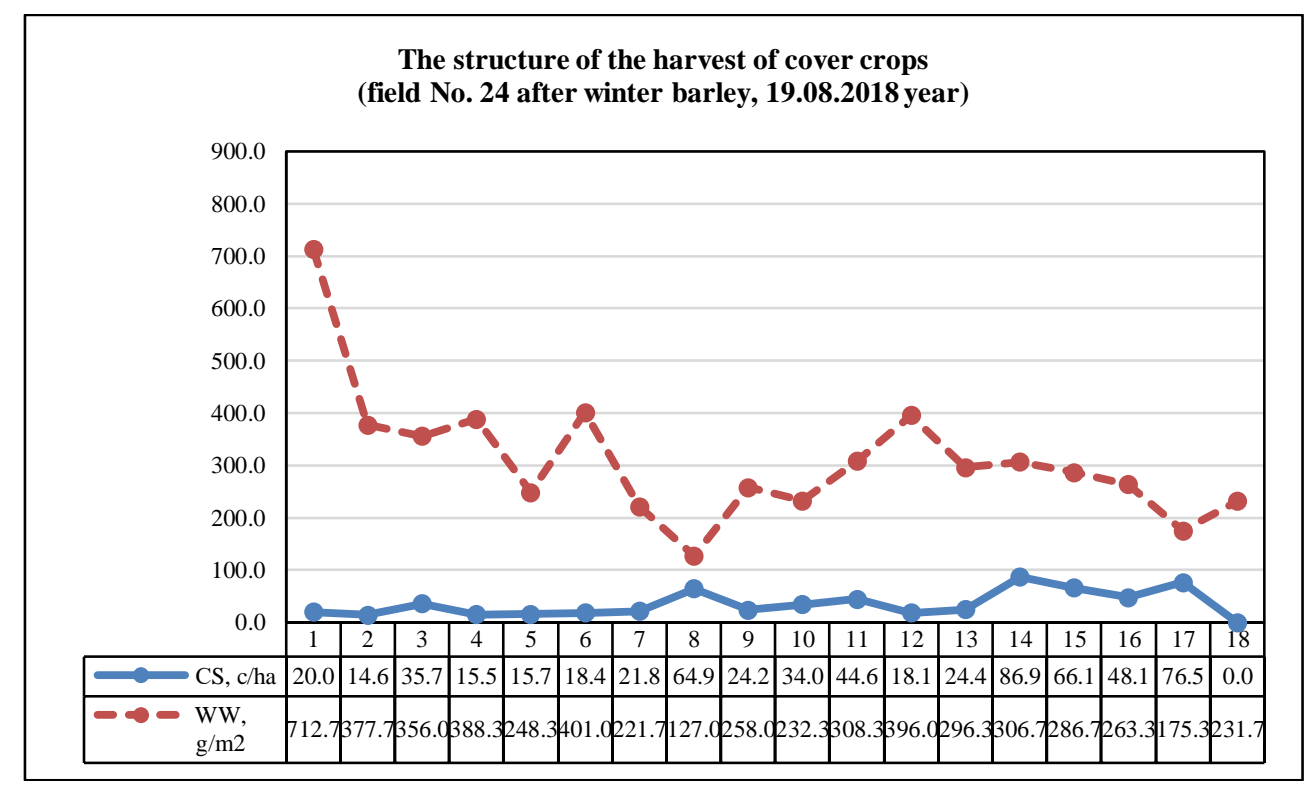

Fig. 3. The weight of cultivated and weed plants during the growing of intermediate groundcover crops in the winter barley-peas crop rotation link.

Analyzing the structure of multi-component harvest of the cover crop cultivated in 2018, the predecessor of winter barley, we set a maximum yield on the plot № 14 (mix of 5 cultures) $-86,9 \mathrm{~kg} / \mathrm{ha}$, the other options are significantly reduced yields at $\mathrm{SSD}_{05}=7.5$ c/ha. However, in this plot (option № 14) and weight of weeds was maximum of $30.6 \mathrm{c} / \mathrm{ha}$ and the minimum mass of weeds recorded at 17-th plot (a mix of 13 crops) $-17.5 \mathrm{c} / \mathrm{ha}$ at $\mathrm{SSD}_{05}=14.4 \mathrm{c} / \mathrm{ha}$. Thus, the highest proportion of cultivated plants to weeds was found in plot № 17 (a mixture of 13 crops) both by weight and by the number of plants. Thus, the more crop components are included in the mix in intermediate groundcover crops, the higher competition is created for the growth and development of weeds. 


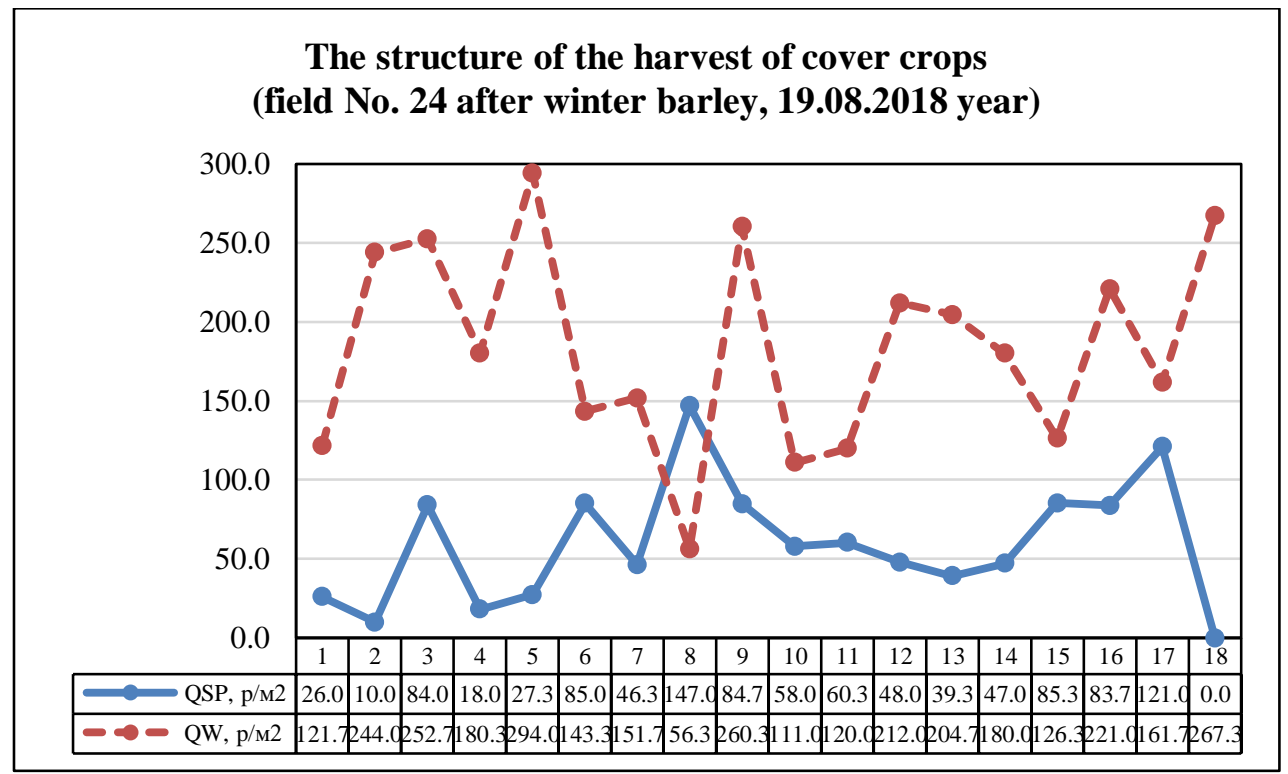

Fig. 4. The number of cultivated and weed plants during the growing of intermediate groundcover crops in the winter barley-peas crop rotation link.

In the compound of weeds after winter barley the following species dominate:

Option № 7 - ragweed (Ambrósia artemisiifólia) - 14pcs $/ \mathrm{m}^{2}$; field sow (Sónchus arvénsis) - $28 \mathrm{pcs} / \mathrm{m}^{2}$; annual Chistets (Stáchys ánnua) - $10 \mathrm{pcs} / \mathrm{m}^{2}$; Cereals - $100 \mathrm{pcs} / \mathrm{m}^{2}$;

Option № 13 field Bindweed (Convōlvulus arvēnsis) - $97 \mathrm{pcs} / \mathrm{m}^{2}$; annual Chistets (Stáchys ánnua) - $91 \mathrm{pcs} / \mathrm{m}^{2}$; Cereals - $17 \mathrm{pcs} / \mathrm{m}^{2}$;

Option № 14 field Bindweed (Convōlvulus arvēnsis) - $40 \mathrm{pcs} / \mathrm{m}^{2}$; annual Chistets (Stáchys ánnua) - $52 \mathrm{pcs} / \mathrm{m}^{2}$; Cereals - $88 \mathrm{pcs} / \mathrm{m}^{2}$;

Option №15 ragweed (Ambrósia artemisiifólia) - 29 pcs $/ \mathrm{m}^{2}$; annual Chistets (Stáchys ánnua) - $28 \mathrm{pcs} / \mathrm{m}^{2}$; Cereals - $59 \mathrm{pcs} / \mathrm{m}^{2}$;

Option № 16 ragweed (Ambrósia artemisiifólia) - $14 \mathrm{pcs} / \mathrm{m}^{2}$; Cereals - $74 \mathrm{pcs} / \mathrm{m}^{2}$; Milkweed (Euphórbia virgáta) - $4 \mathrm{pcs} / \mathrm{m}^{2}$;

Option № 17 ragweed (Ambrósia artemisiifólia) - $3 \mathrm{pcs} / \mathrm{m}^{2}$; field Bindweed (Convōlvulus arvēnsis) - 99 pcs $/ \mathrm{m}^{2}$; annual Chistets (Stáchys ánnua) - $17 \mathrm{pcs} / \mathrm{m}^{2}$; Cereals $41 \mathrm{pcs} / \mathrm{m}^{2}$

Option № 18 field Oats (Sónchus arvénsis) - $6 \mathrm{pcs} / \mathrm{m}^{2}$; field Bindweed (Convōlvulus arvēnsis) - $72 \mathrm{pcs} / \mathrm{m}^{2}$; annual Chistets (Stáchys ánua) - $90 \mathrm{pcs} / \mathrm{m}^{2}$ Cereals - $100 \mathrm{pcs} / \mathrm{m}^{2}$.

\section{Conclusion}

1. The soil density of the arable layer $(0-30 \mathrm{~cm})$ between options with intermediate ground cover crops and without them was almost the same and was in the optimal range - from $1.18 \mathrm{~g} / \mathrm{cm}^{3}$ (under oil radish) to $1.28 \mathrm{~g} / \mathrm{cm}^{3}$ (under oats, radish and vicia as a mixture).

2. The optimal number of pores in the arable layer was observed only in three options of ground cover crops - winter rape + vicia $(55.0 \%)$, oilseed radish $(56.2 \%)$ and a cocktail of five crops $(55.6 \%)$ : corn + peas + flax + sunflower + lentils. At the same time, in all the studied options the total porosity was higher in the upper $0-10 \mathrm{~cm}$ layer of the soil on average by $4.5 \%$ compared to the lower $10-30 \mathrm{~cm}$ layer.

3. The optimal proportion of capillary and non-capillary pores was formed under vicia, oats and radish, as well as a mixture of oats, radish and vicia; less optimal - under winter 
rape, both in pure form and in a mixture with vicia. In the option with a five-component mixture as well as under the control (without intermediate groundcover crops) the number of capillary pores exceeded non-capillary ones by 2.2 times.

4. The reserves of available moisture in one meter layer at the level of satisfactory (90$130 \mathrm{~mm}$ ) on average per years of research have been formed in the option with vicia $107,6 \mathrm{~mm}$ and under the control (without ground cover crop) - 99,6 $\mathrm{mm}$. The lowest stocks of plant-available moisture were in the option with winter rape, both in pure form $(59,3$ $\mathrm{mm})$, and in mixture with vicia $(44,9 \mathrm{~mm})$ - very bad $(<60 \mathrm{~mm})$.

5. The favorable soil structure was formed on 4 studied options: № 4 winter rye + winter rape (61.9\%), № 6 winter rape + winter vicia $(59.5 \%)$, № 12 radish + vicia $(59.8 \%)$ and № 13 oats + radish + vicia $(62.2 \%)$; unsatisfactory - on the options №1 with winter rye (42.3\%), № 10 with oats and radish (42\%), № 16 with a mixture of 10 crops $(45.8 \%)$ and under the control 2 (№19) with the traditional system of agriculture (48.2\%) under the $\mathrm{SSD}_{05}=11.4$.

6. The highest yield of groundcover crops when growing them after winter wheat was obtained by using 5, 8, and 10 component mixtures for sowing - № 14, 15, and 16 (from 10.8 to $12.2 \mathrm{t} / \mathrm{ha})$. The lowest yield was shown by plot \#1 - winter rye $(1.2 \mathrm{t} / \mathrm{ha})$.

7. After winter barley on average during the years of research the maximum yield of the green mass of groundcover crops (from 4.9 to 6.9 t/ha) was noted in the options using multicomponent mixtures (№15, 16, 17), which is 2 or more times higher than the yield of intermediate groundcover crops from 1-2 and 3 spring crops.

8. By the end of the growing season of spring crops $30-33 \mathrm{~kg}$ of nitrogen, $4-5.9 \mathrm{~kg}$ of phosphorus and 13.9-16.7 kg of potassium were accumulated in the plants and in the root system (in the 0-30 cm layer) per sowing hectare.

9. In comparison with the control the studied options had different effects on the accumulation of $\mathrm{P}_{2} \mathrm{O}_{5}, \mathrm{~K}_{2} \mathrm{O}$ and organic matter in the 0-30 cm soil layer. The best results for the content of $\mathrm{P}_{2} \mathrm{O}_{5}$ in the soil were provided by the combination of the no-till system with sowing of cover mixtures of winter rye with winter rape $(65.6 \mathrm{mg} / \mathrm{kg})$ or vicia $(65.8 \mathrm{mg} / \mathrm{kg})$ at $\mathrm{SSD}_{05}=5.43 \mathrm{mg} / \mathrm{kg}$.

10. The yield of Bertha corn hybrid grown after the studied groundcover crops varied greatly over the years from 22 to $33.8 \mathrm{c} / \mathrm{ha}$. Although in 2018 the maximum yield of corn was obtained on plots after cultivation of multicomponent mixtures (№15, 16, 17) and on control plots (№18 and 19), but in 2019 and on average for 2 years of research the difference in yield depending on the cultivation of groundcover crops was not discovered.

11. In general it can be noted that for 2 years of research there were no significant differences in the influence of different options of intermediate groundcover crops on the main agrophysical characteristics of the soil because of the fact that these researches were conducted during the transition period from the traditional farming system to the no-till system. For more reliable conclusions it is necessary to continue to run the research in this area for at least 5 years.

\section{References}

1. R.A. Fischer, D.J. Connor, Field Crops Research 2221, 121-142 (2018) https://doi.org/10.1016/j.fcr.2018.03.008

2. R. Lal, Advances in Agronomy 145, 167-204 https://doi.org/10.1016/bs.agron.2017.05.003

3. Y.P. Dang, N.P. Seymour, S.R. Walker, M.J. Bell, D.M. Freebairn, Soil and Tillage Research 152, 104-114 (2015) https://doi.org/10.1016/j.still.2015.03.009

4. A. Ahsan Bajwa, Crop Protection 65, 105-113 
https://doi.org/10.1016/j.cropro.2014.07.014

5. P. Mehra, J. Baker, R.E. Sojka, N. Bolan, R. Gupta, Advances in Agronomy 150, 185230 (2018) https://doi.org/10.1016/bs.agron.2018.03.002

6. N.J. Sithole, L. Samukelo Magwaza, P.L. Mafongoya, Soil and Tillage Research 162, 55-67 (2016) https://doi.org/10.1016/j.still.2016.04.014

7. I. Martínez, A. Chervet, P. Weisskopf, W.G. Sturny, T. Keller, Soil and Tillage Research 163, 141-151 (2016) https://doi.org/10.1016/j.still.2016.05.021

8. U.E. Prechsla, R. Wittwerab, M.G.A. van der Heijdenabc, G. Lüschera, P. Jeannereta, $\begin{array}{lllll}\text { T. Nemeceka, Agricultural Systems } & \text { 157, } & 39-50 \quad \text { (2017) }\end{array}$ https://doi.org/10.1016/j.agsy.2017.06.011

9. A. Fiorini, R. Boselli, S. Amaducci, V. Tabaglio, European Journal of Agronomy 99, 156-166 (2018) https://doi.org/10.1016/j.eja.2018.07.009

10. S.N. Guto, N. de Ridder, K.E. Giller, P. Pypers, B. Vanlauwe, Field Crops Research 132, 129-138 (2012) https://doi.org/10.1016/j.fcr.2011.10.014

11. V. Nichols, N. Verhulst, R. Cox, B. Govaerts, Field Crops Research 183, $56-68$ (2015) https://doi.org/10.1016/j.fcr.2015.07.012

12. I. Gura, P.N.S. Mnkeni, Geoderma 337, 927-934 (2019) https://doi.org/10.1016/j.geoderma.2018.10.042

13. R. Ordóñez-Fernández, M. Angel Repullo-Ruibérriz de Torres, J. Márquez-García, M. Moreno-García, R.M. Carbonell-Bojollo, European Journal of Agronomy 95, 1-13 (2018) https://doi.org/10.1016/j.eja.2018.02.001

14. G.S. Marcillo, S. Carlson, M. Filbert, T. Kaspar, A. Plastina, F.E. Miguez, Maize system impacts of cover crop management decisions: A simulation analysis of rye biomass response to planting populations in Iowa (USA, 2019) https://doi.org/10.1016/j.agsy.2019.102651

15. P. Bilsborrow, J. Cooper, C. Tétard-Jones, D. Średnicka-Tober, S. Wilcockson, European Journal of Agronomy, 51, 71-80 (2013) https://doi.org/10.1016/j.eja.2013.06.003 